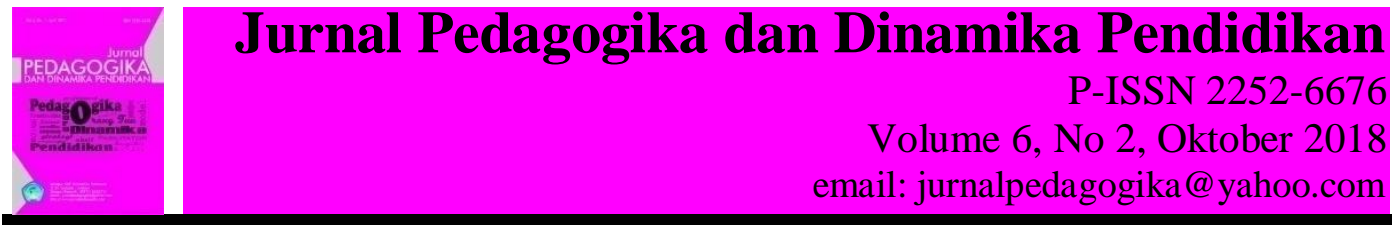

\title{
PEMBELAJARAN TARI MERAK BAGI SISWA TUNAGRAHITA RINGAN DI SLB C CIPAGANTI BANDUNG
}

Intan Purnamasari ${ }^{1}$, Trianti Nugraheni ${ }^{2}$, Putri Lilis Dyani ${ }^{3}$

Alumni Pendidikan Seni Tari, FPSD, UPI-Bandung ${ }^{1)}$

Dosen pada Departemen Pendidikan Seni Tari, FPSD, UPI-Bandung ${ }^{2) 3)}$

e-mail :Intansaripurnama@gmail.com

\begin{tabular}{|c|c|}
\hline ARTICLE INFO & ABSTRACT \\
\hline $\begin{array}{l}\text { Article History: } \\
\text { Accepted 27-09-2018 } \\
\text { Available online 29-10- } 2018 \\
\end{array}$ & $\begin{array}{l}\text { Learning Merak Dance For Lightweight } \\
\text { Students Of Disabilities At SLB C Cipaganti } \\
\text { Bandung.This research is the background of }\end{array}$ \\
\hline $\begin{array}{l}\text { Keywords: } \\
\text { Learning, Media, Model and } \\
\text { Evaluation of learning. }\end{array}$ & $\begin{array}{l}\text { the difficulty of dance learning for children } \\
\text { with lightweight disabilities. Learning dance } \\
\text { at SLB C Cipaganti Bandung has a high } \\
\text { level of difficulty when compared with } \\
\text { dance learning in ordinary schools, Because } \\
\text { the students are lightweight children with } \\
\text { disabilities, who have difficulty in motor and } \\
\text { concentration, while in dancing is needed } \\
\text { strong motion, concentration and memory } \\
\text { On every movement on a dance. This study } \\
\text { aims to determine the Learning Process, } \\
\text { Media, Methods and evaluation used in } \\
\text { Learning Dance Merak For Students } \\
\text { lightweight disabilities in SLB C Cipaganti } \\
\text { Bandung. Approach in this research is } \\
\text { qualitative with research method used is } \\
\text { Descriptive. The result of the research shows } \\
\text { that in the learning of Merak dance in SLB C } \\
\text { Cipagati Bandung from learning process, } \\
\text { media and methods and learning evaluation } \\
\text { have not run well where the dance teacher is } \\
\text { not from dance education, the teacher does } \\
\text { not make the learning planning, the learning } \\
\text { is done according to his experience. And } \\
\text { Besides, the lack of interest in learning } \\
\text { Studentsdance Merak. }\end{array}$ \\
\hline
\end{tabular}




\section{PENDAHULUAN}

Undang-undang Republik Indonesia tentang sistem Pendidikan Nasional No. 20 tahun 2003 pasal 32 ayat 1 bahwa "Pendidikan khusus merupakan pendidikan bagi peserta didik yang memiliki tingkat kesulitan dalam mengikuti proses pembelajaran karena kelainan fisik, emosional, mental, sosial dan memiliki kecerdasan atau bakat tertentu".

Melalui pembelajaran para peserta didik dapat diarahkan, dibimbing serta dibina untuk melakukan berbagai kegiatan belajar, sehingga akan mendorong perkembangan mereka sesuai dengan tujuan Pendidikan Nasional bangsa Indonesia. Permana (1999: 126) mengemukakan bahwa pengajaran merupakan suatu rangkaian yang mempunyai tujuan pengajaran. Belajar terjadi perubahan tingkah laku yang relatif tetap dan sebagai hasil latihan dan pengalaman.

Oemar Hamalik (2011:57), mengemukakan bahwa, "pembelajaran adalah kombinasi yang tersusun meliputi unsur-unsur manusiawi, material, fasilitas, perlengkapan dan prosedur yang saling mempengaruhi untuk mencapai tujuan pembelajaran". Tujuan pembelajaran perlu adanya komponen pendukung pembelajaran yang lain.

Menurut Suyanto dan Djihad Hisyam (2010: 81), komponen-komponen pembelajaran tersebut harus mampu berinteraksi dan membentuk sistem yang saling berhubungan, sehingga mampu menciptakan proses pembelajaran yang berkualitas. Komponen-komponen tersebut antara lain: a) tujuan pembelajaran, b) bahan pembelajaran, c) metode p`embelajaran, d) media pembelajaran, e) guru dan pendidik, f) siswa, g) penilaian dan evaluasi.

Berdasarkan beberapa pendapat yang telah dipaparkan, maka dapat disimpulkan secara sederhana bahwa pembelajaran merupakan suatu proses perubahan ke arah lebih baik yang dilakukan oleh siswa dan didukung oleh guru sebagai komponen pendidik dengan prosedur dan sistem pembelajaran yang baik, sehingga tujuan pembelajaran dapat tercapai.

Kegiatan pembelajaran Tari diharapkan dapat membantu menyalurkan bakat dan merangsang pola pikir anak tunagrahita ringan. Dalam penyampaian materi untuk anak tunagrahita ringan pada kegiatan pembelajaran seni tari bukan suatu hal yang mudah seperti cara penyampaian materi pada umumnya. Ketidakmampuananak tunagrahita ringan menerima materi dalam bentuk teori, maka dialihkan pada penguasaan keterampilan melalui kesenian.

Hasil penelitian Rariek (1980) yang terdapat pada buku Astati (2001 :5) menyatakan bahwa 'kematangan motorik anak tunagrahita ringan lebih lemah daripada anak normal yang seusia dengannya.' Anak tunagrahita mempunyai gerak motorik yang kurang terkoordinir dan terlihat kaku, meskipun keadaan motorik anak tunagrahita ringan tampak tidak berbeda dengan anak normal lainnya, hanya saat melakukan kegiatan motorik jelas nampak keterlambatan kemampuan motoriknya.Untuk ini dalam mengajarkannya harus banyak memberikan latihan-latihan motorik dengan banyak bergerak melalui permainan atau latihan tari.Selain bermasalah dalam motorik, anak tunagrahita juga memiliki hambatan mengenai konsentrasi. 
Hambatan konsentrasi pada anak tunagrahita ditandai dengan adanya tingkah laku seperti tidak mendengarkan dengan baik, tidak mampu mengikuti instruksi, mudah teralihkan perhatian dan mudah lupa dengan aktivitas sehari-hari. Meskipun menunjukkan keterbatasan lingkup perhatian, mudah terganggu perhatian, hiperaktif dan pasif diam berjam-jam" (Astati,2001:6). Masalah konsentrasi ini menyebabkan anak menjadi cepat lupa terhadap atensi yang diberikan.

Dalam melaksanakan tari Merak diperlukan sekali kemampuan motorik yang kuat/tinggi, konsentrasi dan ingatan untuk mengingat langkah-langkah melakukan gerakan tari Merak. Namundemikian telah kita sadari bahwa karakteristik anak tunagrahita ringan dalam kecerdasan adalah dibawah rata-rata yang mengalami kesulitan berpikir, mudah terganggu perhatian dan cepat lupa serta motorik yang lebih lemah dari anak normal.

Untuk itu keberhasilan dalam pembelajaran tidaklah begitu mudah apa lagi yang diajar adalah anak yang berkebutuhan khusus (Tunagrahita Ringan), dalam penelitian ini peneliti akan melihat bagaimana proses pembelajaran yang dilakukan oleh guru terhadap anak tunagrahita ringan, dalam proses pembelajaran yaitu tari Merak, dimana Tari Merak merupakan tarian tradisional yang berasal dari daerahJawa Barat, makna dari tarian Merak ini terdapat pada gerakannya yang ceria dan gembira, sehingga tarian Merak ini cocok untuk melatih motorik dan melatih konsentrasi anak tunagrahita ringan, akan tetapi tari Merak merupakan tari baku. Berbeda dengan tari kreasi yang lain, maka dari itu peneliti ingin mengamati cara guru melakukan proses pembelajaran kepada siswa tunagrahita ringan di SLB C Cipaganti Bandung.

Bagi setiap guru, dituntut untuk melaksanakan proses pembelajaran dengan baik dari awal sampai dengan proses evaluasi, jika ada salah satu komponen pembelajaran yang bermasalah, maka proses belajar-mengajar tidak dapat berjalan dengan baik. Apalagi yang diajarkan adalah anak tunagrahita ringan, yang mengalami kesulitan dalam motorik dan konsentrasi, sedangkan dalam menari sangat dibutuhkan gerak yang kuat, konsentrasi dan ingatan pada setiap gerakangerakan pada suatu tarian. Ini menjadi tantangan besar dalam kegiatan pembelajaran menari pada anak tunagrahita.Berdasarkan uraian di atas maka peneliti tertarik untuk meneliti dengan judul "Pembelajaran Tari Merak Bagi Siswa Tunagrahita Ringan Di Slb C Cipaganti Bandung”.

\section{METODE}

Metode yang digunakan dalam penelitian ini adalah deskriptif dan sebagai dasar pemikiran penelitian metode ini adalah bahan masalah merupakan fakta pada masa sekarang yaitu masalah yang diteliti terjadinya pada saat proses penelitian berlangsung. Narbuko dan Achmad (2009, hlm. 44 ) mengemukakan bahwa:Penelitian deskriptif yaitu pendekatan yang berusaha untuk menuturkan pemecahan masalah yang ada sekarang berdasarkan data-data, menyajikan data, menganalisa dan menginterpretasikan bersifat komparatif dan korelatif yang bertujuan untuk memecahkan masalah secara sistematis dan faktual. 
Tempat penelitian disini mengambil latar di SLB C Cipaganti Bandung. Penelitian ini dilakukan kepada siswa tunagrahita ringan yang berada di kelas pembelajaran tari Merak dan peneliti melakukan penelitian pada jam pelaksanaan menari Merak. Ada dua sumber data, yaitu sumber data primer dan data sekunder. Sumber data primer adalah narasumber pokok dalam penelitian yaitu guru seni tari, sedangkan sumber data sekunder adalah sumber data pendukung yang dalam penelitian ini yaitu siswa tunagrahita ringan, kepala sekolah SLB C Cipaganti Bandung.

Proses pengumpulan data dalam penelitian studi deskriptif ini menggunakan beberapa teknik penelitian, yaitu wawancara, observasi, studi dokumentasi, dan studi literatur.Pada penelitian ini peneliti melakukan Observasi (pengamatan) secara langsung dan bertindak sebagai participant observasi (observasi berpartisipasi) untuk memperoleh data mengenai proses pembelajaran Tari Merak mulai dari proses pembelajaran, media dan metode yang digunakan sampai dengan evaluasi yang digunakan serta mengetahui kondisi dan motivasi siswa dalam pembelajaran tari Merak. Observasi dilakukan dengan dua tahap yaitu : (1) Tahap mencari lokasi penelitian guna memperoleh data yang tepat (2) Tahap mengamati proses pembelajaran.

Dalam penelitian ini peneliti melakukan proses wawancara kepada Subjek penelitian yaitu Wakil kepala sekolah, Guru seni tari dan Tiga orang siswa mengenai masalah yang menjadi fokus penelitian.Pada penelitian ini, peneliti diberikan informasi data yang dibutuhkan, peneliti memilih subjek penelitian yaitu wakil kepala sekolah, guru seni tari dan tiga orang siswa dikarenakan mereka yang terlibat dalam penelitian ini sebagai narasumber dan objek peneliti.Hasil wawancara diharapkan dapat mengumpulkan data tentang Komponen pembelajaran dari proses pembelajaran sampai pada cara mengevaluasi di SLB C Cipaganti Bandung. Kegiatan wawancara ini dilaksanakan pada saat jam pelajaran ekstrakurikuler tari, serta pada jam istirahat sekolah.

Dalam teknik pengumpulan data yaitu dokumentasi merupakan teknik yang akurat dapat membantu memberikan data di dalam menganalisis, mencari data dan mengenai hal -hal variabel yang berupa benda tertulis, seperti buku-buku, majalah, dokumen, peratuaran, notulen rapat, catatan harian, dan sebagainya (Suharsimi Arikanto, 2002:135) Dalam penelitian ini peneliti mengumpulkan data melalui foto-foto yang diambil saat proses penelitian dilakukan pada tanggal 18 Maret 2017, dengan harapan dapat memberikan gambaran situasi yang sebenarnya pada saat itu. Dokumentasi ini juga membantu menjelaskan data, karena keterbatasan peneliti dalam meneliti. Dan yang terakhir teknik pengumpulan data literatur, Faisal (1992, hlm. 30) menjelaskan bahwa "hasil studi literatur bisa dijadikan masukan dan landasan dalam menjelaskan dan merinci masalah-masalah yang akan diteliti; termasuk juga memberi latar belakang mengapa masalah tadi penting diteliti.

Teknik analisis data adalah suatu upayapengolahan data yang diambil dari hasil observasi, wawancara, dan dokumentasi yang kemudian direduksi. Hasil 
pengambilan data kemudian disajikan dan disimpulkan serta diverifikasi untuk memperoleh simpulan data yang benar. Sumaryanto (2007:105) menyatakan bahwa proses analisis data dimulai dengan menelaah seluruh data yang tersedia dari berbagai sumber, yaitu wawancara, pengamatan, yang sudah ada tertulis dalam catatan lapangan, dokumen pribadi, dokumen resmi, gambar, foto, dan sebagainya.

Langkah-langkah analisis data dilakukan secara sistematis dan serempak melalui proses pengumpulan data, mereduksi, mengklasifikasi, mendeskripsikan, dan menyajikan semua informasi secara efektif telah terkumpul. Proses pengumpulan data yang dimaksud adalah mengumpulkan dan menyeleksi data yang diperoleh, selanjutnya menyederhanakan dengan cara mengurangi atau membuang yang tidak perlu kemudian mengelompokkannya secara terpisahsesuai bentuk dan jenisnya.

Langkah selanjutnya menguraikan dan menyajikan data serta penarikan kesimpulan secara selektif telah terkumpul. Langkah-langkah analisis data digunakan untuk memberikan penjelasan secara keseluruhan tentang prosespembelajaran, Media, Metode dan Evaluasi pembelajaran Tari Merak pada tunagrahita ringan di SLB C Cipaganti Bandung yang menjadi pokok permasalahan.

\section{HASIL DAN PEMBAHASAN}

HASIL PENELITIAN

\section{a. Proses Pembelajaran Tari Merak Bagi Siswa Tunagrahita Ringan di SLB \\ C Cipaganti Bandung.}

Berdasarkan hasil penelitian melalui wawancara diperoleh informasi bahwa proses pembelajaran sebelum dilakukan guru memberikan Apersepsi seperti memberikan pengarahan, memberikan pemahaman kepada siswa manfaat dari pembelajaran Tari Merak, kemudian langsung memberikan materi/gerakan yang akan diajarkan. Langkah-langkah yang dilakukan dalam proses pembelajaran yaitu yang pertama melakukan persiapan atau perencanaan, kemudian tahap pelaksanaan, dan tahap penilaian (Evaluasi) dalam melakukan langkah-langkah pembelajaran guru mengalami kendala seperti Anak suka grogi, belum percaya diri dalam melakukan gerakan, ada beberapa gerakan anak belum mampu melakukannya, dibutuhkan pengajaran yang berulang-ulang, sehingga anak membutuhkan waktu lama untuk memahami gerakan-gerakan yang diajarkan khususnya Tari Merak, untuk itu Guru Tari mencari cara untuk mengatasi masalah tersebut, karena beliau sadar anak yang diajarkan adalah anak tunagrahita yang harus memerlukan perhatian khusus, cara yang dilakukan dalam mengatasi masalah tersebut menurut keterangan guru tari tersebut dia berupaya untuk memberikan materi/gerakan tari Merak semaksimal mungkin agar anak bisa memahami, dan melakukan gerakan-gerakan secara berulang sampai anak mampu memahaminya dan selalu memberikan semangat kepada siswa.

Untuk membuat siswa senang dalam mengikuti pembelajaran Tari Merak, guru katakan bahwa dari segi gerakan, penggunaan musik, suasana anak dan 
siswa paling senang ketika menari menggunakan kostum, untuk penguasaan gerakan anak bisa menguasai gerakan 2-3 kali pertemuan tergantung kemampuan siswa dalam menangkap gerakan yang diajarkan, inti dari menari selain mengasah keterampilan Tari Merak dilakukan agar siswa senang dan ceria, cara yang dilakukan agar siswa senang dalam melakukan pembelajaran Tari Merak yaitu dihibur diajak komunikasi, selain diberikan pembelajaran tari Merak disamping itu anak juga diberikan tari kreasi yang membuat siswa lebih bebas ber-eksplore, sehingga siswa tidak bosan dalam belajar menari khususnya tari Merak, dan lebih banyak melakukan pendekatan kepada siswa.Dari hasil penelitian melalui wawancara di atas peneliti berasumsi bahwa dalam proses pembelajaran yang dilakukan oleh guru seni tari pada SLB C Cipaganti Bandung tidak ada perencanaan standar isi, tetapi sesuai dengan pengamatan peneliti, melihat bahwa pembelajaran yang dilakukan hanya bersifat praktek oleh guru tari, siswa diberikan contoh gerakan dan mereka mengikutinya, langkah-langkah yang dilakukan oleh guru tari tersebut dengan cara memberikan arahan kepada siswa kemudian mempraktekkan apa yang dicontohkan setelah itu beliau mengevaluasi tercapaian siswa, dalam melakukan langkah-langkah dimana guru tersebut mendapat kendala seperti ketidakseriusan anak dalam mengikuti gerakan, sehingga membutuhkan waktu ekstra dalam membimbing anak-anak. Cara yang dilakukan oleh guru seni tari tersebut untuk mengatasi anak-anak yang tidak memperhatikan yaitu dengan cara memutar musik dengan suara yang kencang, kemudian penggunaan kostum, dan mengajak berkomunikasi dengan siswa.

\section{b. Media yang digunakan dalam Pembelajaran Tari Merak Bagi Siswa Tunagrahita Ringan di SLB C Cipaganti Bandung}

Media Pembelajaran merupakan salah satu penunjang yang sangat mendukung dalam keberhasilan kegiatan belajar mengajar ( KBM ). Kelengkapan alat dan tersedianya tempat merupakan salah satu kunci kegiatan pembelajaran dapat berjalan dengan lancar.Kegiatan pembelajaran seni tari walaupun dalam lingkup kegiatan ekstra kurikuler, tetap harus menggunakan sarana dan media yang tepat juga.Selain untuk mendukung lancarnya pelaksanaan pembelajaran, serta untuk mempermudah tersampaikan materi yang diberikan guru kepada siswa.

Di SLB C Cipaganti Bandung, sarana dan media untuk pembelajaran menjadi sangat penting dan diutamakan guna pencapaian tujuan pembelajaran di SLB C Cipaganti Bandung yang merupakan visi dan misi sekolah. Begitu pula dengan pembelajaran seni tari, walaupun posisi seni tari pada kegiatan ekstra kurikuler dalam pelaksanaan penyampaian materi juga membutuhkan beberapa kelengkapan alat untuk tercapainya materi yang akan disampaikan melalui kegiatan praktek.

Biaya belanja dan pengadaan sarana dan prasarana didapatkan dari anggaran rutin tahunan sekolah serta komite yang diadakan setiap tahun pelajaran baru. Segala sesuatu yang masih kurang dan belum ada di tahun pelajaran sebelumnya akan segera dipenuhi pada tahun ajaran baru untuk lebih meningkatkan kelancaran 
belajar walaupun dengan dana yang minim. Sarana dan media yang ada untuk kegiatan ekstra kurikuler tari di SLB C Cipaganti Bandung sebagai antara lain Ruang praktek, Sound System dan Terminal , Laptop dan Handphone dan Kostum Tari Merak

\section{c. Metode yang digunakan dalam Pembelajaran Tari Merak bagi siswa Tunagrahita Ringan di SLB C Cipaganti bandung.}

Metode pembelajaran tari yang digunakan guru dalam menyampaikan materi kepada anak-anak sesuai pengamatan peneliti pada dasarnya sama dengan anak-anak normal lainnya. Seperti halnya menggunakan metode ceramah, demonstrasi, penugasan dan latihan (drill).Dari hasil penelitian dilapangan, metode yang digunakan guru untuk menyampaikan materi saat pembelajaran ekstra kurikuler tari di SLB C Cipaganti Bandung adalah metode ceramah, metode demonstrasi, metode latihan dan metode penugasan. Penerapan metode ini tidak semata-mata berdiri sendiri -sendiri melainkan dikombinasikan. Seluruh metode tersebut dipergunakan dalam kegiatan pembelajaran seni tari secara menyeluruh dari kegiatan awal hingga kegiatan menutup pelajaran, meskipun terkadang metode ini tidak terlaksana secara maksimal.

\section{d. Evaluasi dalam pembelajaran Tari Merak bagi siswa Tunagrahita Ringan di SLB C Cipaganti Bandung}

Adapun hasil yang diambil dalam evaluasi yang dilakukan oleh guru, seperti yang tertera pada tabel penilaian berikut.

Hasil Penilaian Siswa Pada Tari Merak

\begin{tabular}{|c|c|c|c|c|c|c|}
\hline \multirow[b]{2}{*}{ No } & \multirow[b]{2}{*}{ Nama Siswa } & \multicolumn{3}{|c|}{ Penilaian } & \multirow[b]{2}{*}{ Nilai } & \multirow[b]{2}{*}{ Hurif } \\
\hline & & Wiraga & Wirama & Wirasa & & \\
\hline 1 & Aimaida jayanti sukandi & 85 & 75 & 80 & 80 & $\mathbf{B}$ \\
\hline 2 & Nisa nurhasanah & 75 & 70 & 65 & 70 & $\mathbf{C}$ \\
\hline 3 & $\begin{array}{l}\text { Nisa nurhasanah Rafli } \\
\text { Maulud }\end{array}$ & 85 & 75 & 75 & 77 & $\mathbf{B}$ \\
\hline 4 & Dewi rahayu & 70 & 70 & 70 & 70 & $\mathbf{C}$ \\
\hline 5 & Elsha & 70 & 65 & 70 & 68 & D \\
\hline 6 & Erni fadillah & 80 & 65 & 75 & 73 & $\mathbf{C}$ \\
\hline 7 & Dania safila azizah & 75 & 70 & 70 & 72 & $\mathbf{C}$ \\
\hline 8 & Ari bastia arifin & 70 & 65 & 70 & 68 & D \\
\hline 9 & Reisha yusup & 75 & 70 & 65 & 70 & $\mathbf{C}$ \\
\hline
\end{tabular}

\section{Keterangan:}

$$
\begin{aligned}
& A=\text { Sangat baik }(90-100) \\
& B=\text { Baik }(80-89) \\
& C=\text { Cukup }(70-79) \\
& D=\text { Kurang (60-69) }
\end{aligned}
$$


Penilaian Nilai (90-100) sangat baik apabila siswa mampu menguasai gerakan tari Merak sesuai dengan penilaian Wiraga, Wirama dan Wirasa. Penilaian (80-89) diberikan kepada siswa apabila siawa melakukan gerakan Tari Merak dengan baik tetapi tidak sempurna dimana dalam evaluasi siswa Aimaida jayanti sukandi dan Nisa nurhasanah Rafli Maulud mendapat nilai B (Baik) dikarenakan ketiga indikator penilaian kedua siswa tersebut melakukannya dengan baik, kedua anak tersebut lebih menonjol dari pada siswa yang lainya.

Penilaian (70-79) apabila siswa dalam melaksanakan proses menari tari Merak anak masih belum baik dalam melaksanakannya dari sisi wiraga, wirama dan wirasa, dimana dalam wiraga siswa belum menguasai gerakan dengan baik, dalam wirama siswa gerakannya tidak mengikuti irama musik dan begitu juga dengan Wirasa anak belum sepenuhnya menghayati gerakan yang diperagakan, pada penilaian cukup sebanyak 5 (lima) anak yang mendapat nilai tersebut (tabel 9). Dan pemberian nilai 60-69 merupakan penilain yang diberikan kepada siswa dikarenakan dalam melaksanakan menari tari Merak siswa dari ketiga indikator penilaian yaitu wiraga, wirama dan wirasa siswa belum cukup atau kurang dalam melakukannya, gerakan yang dilakukan belum sesuai kadang ada yang tidak mau melakukan gerakan yang didemonstrasikan oleh guru, begitu juga wirama dan wirasa.

Pada dasarnya tari Merak sendiri adalah tari tradisional yang gerakannya tidak bisa digantikan, untuk itu dari hasil evaluasi yang dilakukan sebagian besar siswa mendapatkan nilai yang cukup, tetapi menurut hasil wawancara dengan guru pada tanggal 6 Maret 2017 mengatakan bahwa yang paling terpenting adalah melatih motorik anak dan anak sudah mau ikut berpartisipasi dan tertib itu merupakan sebuah kecapaian yang bagus. Dari statement yang disampaikan di atas bisa ditarik kesimpulan bahwa pada dasarnya nilai itu hal yang dinomorduakan, dan yang paling terpenting adalah melatih motorik anak dan melihat perkembangan anak.

\section{PEMBAHASAN HASIL PENILITIAN}

Berdasarkan data hasil penelitian yang telah dikemukakan mengenai, "Pembelajaran Tari Merak Bagi Siswa Tunagrahita Ringan Di SLB C Cipaganti Bandung," maka dapat diuraikan sebagai berikut :

Proses pembelajaran tari Merak yang dilakukan di SLB C Cipaganti Bandung pada dasarnya sama seperti yang dilakukan pada sekolah normal pada umumnya tetapi dalam proses pembelajaran tari Merak dilakukan secara praktik dan cara penanganannya pun berbeda dimana dalam proses pembelajaran guru mengualang gerakan-gerakan yang belum bisa dilakukan oleh anak secara sempurna untuk itu membutuhkan waktu yang lama dalam menangkap gerakan, dikarenakan anak mempunyai tingkat IQ yang lemah. proses pembelajaran dimulai dengan meningkatkan rasa apersiatif terhadap tari Merak, kemudian, guru memberikan contoh gerakan dan siswa mengikutinya, gerakan yang dilakukan tidak secara menyeluruh tetapi dilakukan secara bertahap dimana setiap 
pertemuan paling banyak mengenalkan tiga gerakan, dan dilakukan secara berulang-ulang.

Pembelajaran merupakan kegiatan yang berproses dan merupakan unsur yang sangat fundamental dalam setiap penyelenggaraan jenis dan jenjang pendidikan teori belajar menurut Syah berarti perubahan yang terjadi dalam proses belajar adalah berkat pengalaman atau praktik yang dilakukan dengan sengaja dan disadari atau dengan kata lain bukan secara kebetulan Syah (2000:7).

Dari teori yang disampaikan oleh Syah diatas bahwa yang terjadi dalam pembelajaran adalah berkat pengalaman dan prakek yang dilakukan dengan sengaja dan disadari atau dengan kata lain bukan secara kebetulan di sini jika dikaitkan dengan pembelajaran yang dilakukan oleh Anggina selaku guru seni di SLB C Cipaganti Bandung, secara terencana seperti pembuatan standar isi Anggina tidak melakukan hal tersebut tetapi hanya melakukan pembelajaran sesuai dengan pengalaman menari yang dimiliki. Adapun dalam pembelajaran dibutuhkan suatu perencanaan dengan sengaja untuk membuat siswa bisa berubah secara kognitif, afektif dan psikomotor.

Suatu kegiatan dapat dikatakan sebagai pembelajaran haruslah dilakukan oleh seorang guru. Guru itu sendiri menurut Wahyu Utomo (2006:13) adalah seseorang yang memiliki kualifikasi dan kompetensi dalam melakukan tugastugas kependidikan serta sebagai pelaksana kurikulum. Mempunyai kualifikasi berarti memiliki latar belakang pendidikan sebagai seorang guru.Memiliki kompetensi berarti memiliki kemampuan, baik secara pengetahuan dan skill maupun secara administratif serta tanggung jawab terhadap tugas-tugasnya.

Jika dilihat dari sisi pendidikan pada guru seni tari di SLB C Cipaganti bandung sesuai hasil Observasi dimana guru seni tari hanyalah lulusan SMALB C Cipaganti Bandung, sesuai pendapat di atas hal tersebut tidak sesuai dengan guru Seni tari yang ada di SLB C Cipaganti Bandung di karenakan secara latar belakang pendidikan bukanlah berpendidikan sebagai seorang guru, secara pengetahuan guru tersebut masih minim, dikarenakan guru tersebut adalah siswa tunagrahita ringan, tetapi guru tersebut mempunyai kemampuan atau skill dalam penguasaan tari.

Media yang digunakan guru dalam membantu proses pembelajaran tari Merak yaitu laptop, handphone, sound system, terminal, kostum dan yang paling membantu adalah ruangan kesenian berupa aula untuk tempat latihan menari. Dimana laptop dan handphone digunakan untuk mengisi musik tari Merak maupun musik-musik tari yang lainnya, sound system digunakan untuk alat pengeras suara dalam memutar musik tari Merak dan kostum sebagai pelengkap dalam melakukan tarian, dan aula merupakan tempat untuk mengadakan latihan atau proses pembelajaran tari Merak khususnya, media dan sarana di atas sangat membantu dalam melakukan proses pembelajaran tari Merak di SLB C Cipaganti Bandung.

Azhar Arsyad (2008:3) mengemukakan bahwa kata media berasal dari bahasa Latin medius yang secara harfiah berarti 'tengah', 'perantara' atau 'pengantar'. Dalam bahasa Arab, media adalah perantara atau pengantar pesan 
dari pengirim kepada penerima pesan.Media apabila dipahami secara garis besar adalah manusia, materi, atau kejadian yang membangun kondisi yang membuat siswa mampu memperoleh pengetahuan, keterampilan, atau sikap.

Dari hasil pengamatan peneliti dimana media dalam membantu proses pembelajaran Tari Merak di SLB C Cipaganti Bandung sudah memadai tetapi yang masih kurang yaitu kostum dalam menari tari Merak di SLB C Cipaganti Bandung kostum Tari Merak hanya memiliki dua kostum, sedangkan siswa yang mengikuti kelas tari Merak berjumlah sepuluh orang siswa.

Guru dalam menyampaikan materi dalam proses pembelajaran tari Merak menggunakan atau mengkombinasikan beberapa metode antara lain menggunakan metode demonstrasi, metode latihan, metode penugasan, metode ceramah dimana metode demonstrasi guru sengaja memberikan gerak yang sederhana dan dipadukan dengan kata-kata yang sederhana pula. Hal ini mengingat kekurangan pada siswa dalam menerima pelajaran.Metode latihan sangat baik dilakukan, karena sebelum anak memulai pelajaran dia bisa melakukan pemanasan terlebih dahulu, mengingat keadaan siswa SLB C Cipaganti Bandung yang kurang normal.Sebelum masuk ke materi pelajaran biasanya anak latihan terlebih dahulu sambil mengingat-ingat gerak yang disampaikan guru kemarin. Metode pemberian tugas ini dengan tujuan untuk lebih memantapkan siswa terhadap materi yang telah dipelajari dan metode ceramah adalah pemberian keterangan secara lisan oleh guru kepada siswa. Guru menerangkan, sedangkan siswa mendengarkan atau memahami dengan teliti.

Definisi metode pembelajaran adalah cara yang digunakan guru supaya siswa memperoleh pengalaman belajar mengenai materi yang disampaikan (Gino, 1993:67). Selanjutnya yang dimaksud dengan metode mengajar ialah cara yang berisi prosedur baku untuk melaksanakan kegiatan kependidikan, khususnya kegiatan penyajian materi pelajaran pada siswa.

Dari pengamatan peneliti di lapangan menyangkut dengan metode yang digunakan di SLB C Cipaganti Bandung hanya beberapa metode yang digunakan dalam pembelajaran tari Merak yang dilakukan oleh Anggina antara lain metode demonstrasi, ceramah, latihan dan penugasan. Metode yang digunakan juga tanpa rencana dibuktikan dengan tidak adanya rancangan pembelajaran yang dilakukan hanya berupa praktik saja.

Guru dalam mengevaluasi menggunakan penilaian perbuatan, indikator penilaiannya yaitu wiraga, wirama dan wirasa, dimana peserta didik selalu melakukan praktik menari, maka dengan penilaian perbuatan akan diperoleh nilai dari hasil keterampilan dan sikap dari peserta didik pada waktu melakukan praktik tari Merak.Evaluasi pembelajaran adalah suatu proses yang berkelanjutan tentang pengumpulan dan penafsiran informasi untuk menilai keputusan yang dibuat dalam merancang suatu sistem pembelajaran (Hamalik, 2002:210).

Jika dilihat dari evaluasi yang digunakan oleh guru seni tari d SLB C Cipaganti Bandung pengukuran keberhasilan siswa dilihat dari penilaian wirasa wirama dan wiraga disamping itu belum adanya perlombaan yang diikuti oleh anak menyangkut dengan tari Merak, dan sesuai dengan pengamatan peneliti 
melihat bahwa anak belum secara sempurna melakukan gerakan tari Merak, dikarenakan keterbatasan kognitif yang dimiliki oleh anak tunagrahita ringan. Disamping itu juga guru yang mengajarkan seni tari juga secara akademik hanya lulusan dari SLB C Cipaganti Bandung, tetapi hanya mempunyai keahlian dalam bidang menari.

\section{KESIMPULAN}

Dengan demikian dalam penelitian ini peneliti menemukan hasil bahwa dalam pemeblajaran tari Merak di SLB C Cipagati Bandung dari proses pembelajaran, media dan metode serat evaluasi pembelajaran belum berjalan dengan baik dimana pada proses pembelajaran gerakan -gerakan yang dilakukan oleh siswa belum sempurna, salah satu indikatornya bahwa guru tari pada SLB C Cipaganti Bandung bukan berasal dari sarjana pendidikan tari tetapi latar belakang pendidikan terakhirnya yaitu SPLB-C, sehingga guru tidak mempunyai standar isi sebagai panduan dalam melakukan pembelajaran, proses pembelajaran dilakukan sesuai dengan pengalaman yang dimiliki, sesuai pengamatan peneliti guru dalam melakukan beberapa gerakan tari merak seperti gerakan contoh Sindet masih belum sempurnah di peragakanya. Selain itu siswa pada SLB C Cipaganti bandung yang tertarik/berminat dalam melakukan praktek tari merak maupun tari tradisonal lainya sangatlah sedikit dibandingkan dengan tari modern.

\section{DAFTAR PUSTAKA}

Amin.Moh.(1995). Ortopedagogik Anak Tunagrahita. Bandung: Depdikbud

Arikunto, Suharsimi. 2007. Dasar-dasar Evaluasi Pendidikan. Jakarta: PT. Rineka Cipta.

Arif. S. Sadiman. (2003). Media Pendidikan: Pengertian, Pengembangan dan Pemanfaatannya.Jakarta : PT Raja Grafindo Persada.

Arsyad,Azhar. 2008. Media Pembelajaran. Jakarta: PT Raya Grafindo

Astati.(2001). Persiapan Pekerjaan Penyandang Cacat Tunagrahita. Bandung : CV. Pandawa

Astati. (1995). Terapi Okupasi, Bermain dan Musik untuk Anak Tunagrahita, Bandung: Depdikbud

Astati. (1996). Pendidikan dan Pembinaan Karier Penyandang Tunagrahita Dewasa. Bandung: Depdikbud.

Budimansyah, Dasim. Suparlan. Danny Meirrawan. 2010. PAKEM. Bandung: PT. Genesindo

Danim, Sudarwan. 2010. Media Komunikasi Pendidikan. Jakarta: Bumi Aksara.

Depdiknas. (2007). Pedoman Pengembangan Bidang Seni di Taman Kanakkanak. Jakarta.

Departeman Pendidikan Nasional.2003. Kamus Besar Bahasa Indonesia. Jakarta: Balai Pustaka

Dimyati dan Mudjiono.(2009). Belajar dan Pembelajaran. Jakarta: PT Rineka Cipta. 
Gino, H. J. 1993. Belajar dan Pembelajaran I. Surakarta: Depdikbud RIUniversitas Sebelas Maret.

Hamalik, Oemar. (2011). Kurikulum dan Pembelajaran. Jakarta: Bumi Aksara.

Hamalik, Oemar. (2001). Proses Belajar Mengajar.Jakarta : Bumi Aksara.

Hamalik, Oemar ,(2002). Psikologi Belajar Mengajar, Bandung: Sinar Baru Algensindo

Ibrahim, R \& Nana, S.S. 2003.Perencanaan Pengajaran. Jakarta: Depdikbud \&Rineka Cipta

Ismawati, Esti dan Margono Notopertomo. 1995. Perencanaan Pengajaran Bahasa Penuntun bagi Guru Muda dan Mahasiswa Calon Guru dalam MembuatPersiapan Mengajar. Surakarta: CV. Handayani.

Ismawati, Esti. 2009. Metode Penelitian Pendidikan Bahasa dan Sastra. Yogyakarta: Cawanmas.

Jazuli.(2008). Paradigma Kontekstual Pendidikan Seni. Penerbit UNESA University, Semarang.

Jazuli.(1994) Telaah Teoritis Seni Tari. Semarang: IKIP Press

Muhibbin Syah. (2000). Psikologi Pendidikan.Bandung : Remaja Rosda Karya.

Mulyani Sumantri dan Johar Permana, 1999, Strategi Belajar Mengajar, Jakarta :

Direktorat Jendral Pendidikan Tinggi.

Mulyasa.E. (2002).Manejemen Berbasis Sekolah, Konsep, Strategi, dan Implementasi, Bandung. PT. Remaja Rosada Karya.

Mulyasa, E. 2007.Menjadi Guru Profesional Menciptakan Pembelajaran Kreatifdan Menyenangkan. Bandung: PT.Remaja Rosda Karya.

MS Sumantri. (2005). Pengembangan Keterampilan Motorik Anak Usia Dini.Jakarta: Dinas Pendidikan.

Sagala, Syaiful. (2011) konsep dan Pembelajaran. Bandung. Alfabeta

Suyanto dan Djihad Hisyam. (2010). Pendidikan Indonesia Memasuki Milenium III.Yogyakarta: Adicita Karya Nusa.

S.M. Lumbantobing. (2001). Anak dengan Mental Terbelakang. Balai Penelitian

Fakultas Kedokteran Indonesia

Slameto.(2003). Belajar dan Faktor-Faktor yang Mempengaruhinya. Jakarta: PT Rineka Cipta.

Sukmara, Dian. 2003. Implementasi Program Life Skill. Bandung: MughniSejahtera.

Siswanto,( 2007).Kesehatan Mental;Konsep,Cakupan,danPerkembangannya, Yogyakarta : Penerbit ANDI.

Wardani, I.G.A.K. 2007. Penelitian Tindakan Kelas. Jakarta: Universitas Terbuka KTSP SD/MI 2011

\section{Sumber lain :}

Nina Saputri. ( 2011). Pembelajaran Tari Untuk Penyandang Tuna Grahita Ringan Pada Kegiatan Ekstra Kurikuler Tari Di SLB C Widya Bhakti Semarang. Jurusan Pendidikan Sendratasik Fakultas Bahasa Dan Seni Universitas Negeri Semarang. 
Nurinayah.(2014). Pembelajaran Tari Kupu-kupu pada anak Tunagrahita C1 di Sekolah Dasar Luar Biasa (SDLB) Negeri Kedungkandang Kota Malang.

Usi Damayanti. (2016). Kemampuan Psikomotor Dalam Pembelajaran Tari Yamko Rambe Yamko Pada Anak tunagrahita Ringan Kelas 3 SMPLB di SLB C Tunas Kasih 2 Kota Bogor.

Undang-Undang Republik Indonesia Nomor 20 Tahun 2003 Tentang Sistem Pendidikan Nasional

\section{Sumber Internet:}

(http://hoethealth.blogspot.co.id/2016/03/kelengkapan-dan-ragam-gerak-tari merak.html Akses pada tanggal 1 januari 2017).

http://www.senitari.com/2015/10/properti-tari-merak.html Akses pada tanggal 1 januari 2017). 